\title{
THE SO-CALLED “ISLAMIC TERRORISM”: A Tale of the Ambiguous Terminology
}

\author{
Dwi Surya Atmaja \\ Pontianak State Institute of Islamic Studies \\ atmajapontianak@ymail.com
}

\begin{abstract}
"What does the term "terrorism" mean." Why does the term "terrorism" often identified as Islam? "If terrorism is an ism that affects "terror" that it generates, while Islam which literally means "peace", then the two terms certainly mismatch! Such question and statement show Muslims' concern over frequent phenomena of "terrorism" using Islamic religious symbols. The research undertaken proved that there are three explanations. First, a close tripartite network connection between "terrorism experts" and the circles of power policy holders who are also supported by senior journalists in the international media influence. Second, a long tradition of Orientalist studies in the study of the Middle East region and the study of religion in the Arab culture. Figures such as Bernard Lewis, Noah Feldman, Raphael Patai and other Middle East experts often sit with other experts in the field of terrorism (the first factor) and become main advisors and expert staff for the US government in the formulation of action to counter terror. It was the catalyst for the transmission of viewpoint which then decorated orientalist discourse of Islamic terrorism in the process of political policies. Third, a lot of Islamic terrorism discourse refers to the long tradition of cultural stereotypes and biased representations of the media that often portray Islam and Muslims as 'the enemy'. The reason is that it reflects the perspective of socio-Western culture that fears and worries the other oriental parties which has been stereotyped since the imperial era. Many also argue that the dichotomy of the orientalist views are deliberately preserved as a form of new style imperialism.
\end{abstract}

Keywords: Islam, Terrorism, Ambiguous, Terminology

\section{INTRODUCTION}

In general, when the term terrorism is read the spontaneous impression tends to relate to acts of terror, intimidation, horor, violence, damage and losses it may cause. The public often neglects a term with regard to who frequently uses it and what it is used for. In the study of the history of Islamic thought, for example, the term Khawārij and Mu'tazila obviously were derived from within a group, but from outside of the group with different thought 
and understanding, seeking to delegitimize the objective group. The literal meanings of the two terms are those who exit (khawärij) and those who move away (mu'tazila). Although internal parties of the Khawärij are those who do not agree on the choice of arbitration taken, the internal Mu'tazila identify themselves as ahl l- 'adl wa t- tawhīd (supporters of justice and the Oneness). Still the terms Khawärij and Mu'tazila become standard in the discourse of Islamic thought. In other words, each term requires precision of readers to understand who uses it.

The historical aspects of the terms Khawārij and Mu'tazila above should produce our intellectual readiness to observe the term "terrorism", its background and the intended subject and object. For the expansion and legitimacy perspective, the study of the history of the "West" is used as a starting point for the discourse on terrorism terminology.

\section{TERRORISM: A HISTORY OF THE FEAR TOWARDS AN AMBIGUOUS TERMINOLOGY}

In the Western tradition, the term terrorism has been popularly used since the late 1700s. ${ }^{1}$ At a national convention in France, after the success of the revolutionary movement to overthrow the monarchy and marked the ended the rule of the land, Maximilien Robespierre declared that "terrorism" was one of the instruments of government policy system led by a movement. The "terror" policy system was intended to protect the revolutionary government from the threat of enemies of the people who wanted the restoration of the deposed king. ${ }^{2}$ Whereas in English dictionaries, the term terrorism was first recorded in 1798 and defined as 'a systematic use of terror as a policy.' To date, the initial use of the term terrorism generally implies a policy of intimidation used by the government as a method of maintaining power stability.

In the next century, the 1800 s, precisely in 1870 in Russia, a movement of the people introduced themselves as terrorists who resisted the ruling. ${ }^{4}$ A decade

\footnotetext{
${ }^{1}$ There is also a hint that suggests the term "Terror" as the root of the word "terrorism" has been used since 105 BC during the Roman Empire. "Terror Cimbricus" is a term that refers to the riots and the emergency situation in the city of Rome as a result of attacks carried out by the Cimbri tribe to the Roman capital. Mark Burgess, A Brief History of Terrorism, (Washington DC: Center for Defense Information, 2003) at https://www.ciaonet.org/ wps/bum09/diakses tanggal 23 Juli 2013

${ }^{2}$ Myra Williamson, Terrorism, War and International Law: The Legality of the Use of Force against Afghanistan in 2001, (London: Ashgate Publishing, 2009), hal. 38.

${ }^{3}$ Douglas Harper, “Terrorism”, Dictionary.com: Online Etymology Dictionary, at http:// dictionary.reference.com/browse/terrorism, diakses tanggal 23 Juli 2013

${ }^{4}$ Martha Crenshaw, Terrorism in Context, (Penn: Penn State University Press, 1995), hal. 77
} 
later, Johann Most wrote a book entitled "Advice for Terrorists" in $1880^{5}$ containing the resistance of the grassroots. The two forms of resistance above show that the term terrorism has experienced a shift: a policy system that was practiced by the ruler becoming an effort initiated by the grassroots; from the method for power stability to a method for destabilize it.

Apart from who is using it and for what purpose, the existence of terrorism as a method is still widely recognized. Concerns about functional strength of this method, i.e.: 'something horrible' still exists. The real proof of this concern was recorded in the convention of the League of Nations (the precursor to the United Nations), with the theme of prevention and repression of terrorism being held in the 1930s. The Convention then defined terrorism as a 'criminal act targeting the instability of a sovereign State by creating a state of terror in the community life. ${ }^{6}$ The draft of the convention also detailed the activities categorized as criminal acts of terrorism such as:

1. Deliberate crime resulting in death, serious injury or restriction of motion from / to the heads of state or their successor, to the spouse of the head of the State, or against individuals who assume public office so as to disrupt the functions of the office.

2. Massive and structured destruction of public property concerning the lives of many people.

3. Deliberate crime endangering the lives of important public office holders

4. Planned attacks with possible results as mentioned above

5. Production, purchase, possession or supply of weapons, ammunition, explosives, or other dangerous materials that result in crimes as mentioned above. $^{7}$

Despite the fact that later this draft was not enforced, the convention agenda indicated political and emotional connotations of the word 'terrorism'. The definition of this draft represented the interests of rulers who began to shift the stigma of terrorism as a tool of struggle of the oppressed. Initially, terrorism had a positive connotation that contained the spirit of struggle, but after the post-convention of the League of Nations the word began to show its shades of horror. ${ }^{8}$

${ }^{5}$ Martha Crenshaw, Terrorism in Context,..hal. 44

${ }^{6}$ See Roza Pati, Due Process and International Terrorism, (Leiden: Martinus Nijhoff Publisher, 2009), Alex Conte, Human Rights in the Prevention and Punishment of Terrorism, (Heidelberg: Springer, 2010). Myra Williamson, Terrorism, War and International Law: The Legality of the Use of Force against Afghanistan in 2001, (London: Ashgate Publishing, 2009).

${ }^{7}$ See Roza pati, Due Process and International Terrorism, hal. 279.

${ }^{8}$ Prior to the Convention on the League of Nations in 1937, the term terrorism went through a period of turn-over in its connotations. The early days of the formation of the 
Violent acts that create terror in public life as a concern among convention delegates of the League of Nations above began to rise dramatically in some parts of the world after the end of World War I. The historians in the field of regional conflict underlined the interval period between 1914 and 1922 as the embryo of the outbreak of terror aimed at political activity that occured in the following phases. ${ }^{9}$ The territorial break-down of the Middle East and Central Asia which were in a structured management under the rule of the Turkish Ottoman and the German Empire and the Astro-Hungary became small autonomous federal states was the root of the problem. American and European Allies that won World War I and sat in bargaining Paris Peace Conference $^{10}$ enjoyedfull power to lay down the limits of their conquered territory in the area of the oil circle with absolutely no consideration including input from those that had long been the 'rulers.' ${ }^{11}$

The formation of pseudo nation-states established by the champions of the World War I in the form of territorial segregation by placing puppet governments in the Middle East and Central Asia was of course based on the consideration geopolitical dominance to ensure sustainability of control in the region. However, in practice and further developments, it appered to be a

Laws of War were also influenced by the discourse of terrorism in which warring parties often commit barbaric acts in the name of the struggle. In 1899, a general clause called the Martens Clause appeared was widely accepted as war ethics that distinguished the category of acts that were acceptable in war and acts categorized as war crimes. Martens clause was later influenced the views on the term "terrorism". See V. Pustogarov, "Fyodor Fyodorovich Martens (1845-1909) - a Humanist of Modern Times", International Review of the Red Cross (IRRC), No. 312, May-June 1996, hal. 300-314.

${ }^{9}$ See for example D. Fromkin, A Peace to End All Peace: The Fall of the Ottoman Empire and the Creation of the Modern Middle East, (New York: Henry Holt, 1992), I. Hilton, "The Pashtun code" dalam New Yorker, 77(38), (2001), hal, 58-71, dan Ahmed Rashid, Taliban: Militant Islam, Oil and Fundamentalism in Central Asia, (New Haven and London: Yale Nota Bene, 2001)

${ }^{10}$ Paris Peace Conference was an international conference attended by delegates from allies that won the World War I by defeating the coalition of forces of the German Empire and the Ottoman Empire. The meeting which was held in Paris in 1919 was widely attended by heads of state and kings from around the world except Germany and Russia and was initiated by the four major state powers known as The Big Four, namely the United States by President Woodrow Wilson as head of the delegation, British Prime Minister David Lloyd George, the French Prime Minister Georges Clemenceau and Italian Prime Minister Vittorio Orlando. Several agreements achieved in the talks can be regarded as a milestone in the history of the world that determined its next journey. Some of them such as the formation of the League of Nations, the Treaty of Versailles with the German, transfer of territories under the administration of Germany and the Ottoman Empire around the world, especially to Britain and France, as well as the establishment of the boundaries of the new states on the basis of nationalism. See for example, The Editors of Encyclopaedia Britannica, "Paris Peace Conference", Encyclopaedia Britannica, online version at http://global.britannica.com/EBchecked/ topic/443901/Paris-Peace-Conference accessed on 4 November 2013.

${ }^{11}$ D. Fromkin, A Peace to End All Peace..p. 17 
reckless ${ }^{\text {partition } 12}$ which eventually became the precursor of the burning chaos that can never be put out to this day.

Britain and France, two countries that were most responsible for this zoning, each setting a pattern composition of the government system, the authorities, and the segmentation of the population that occupied their new shape. The careless territorialzation arrangement, when viewed from the perspective of potential conflict, was due to the decision of the Paris Conference gave a mandate to the two countries to immediately divided the pie of the dominance over the region in a relatively short time. As a result, factors and objective conditions in field were not carefully taken into consideration. The desire for revenge after the World War I and for expanding and continuing colonialism eventually became the main purpose in the mapping of the territories. Crucial considerations such as backgrounds of custure, ethnicity and tribes, religion, patterns of economic and social networks that had been enacted were neglected and even radically revolutionized. ${ }^{13}$ Bloody communal conflicts finally broke out easily.

In the formation of Iraq, for example, Britain put together the Kurds, Sunni, Shia majority and the Jewish people in a country and installed an Arab prince as a ruler. This decision then led to bloodshed in which the people of Iraq rebelled and responded with the deployment of British troops and led to the loss of 500 lives of the British soldiers and over 6,000 lives of the Iraqi people. ${ }^{14}$ Separation of Trans-Jordan (now Israel) of Arab Palestine ${ }^{15}$ and unification of two native powers of Hindu and Muslim in South Asia in one Indian state as well as the formation of the composition of the tribal authorities in the northern part of Afghanistan as an effort to curb the power of Russia all pose devastating conflicts that claimed many victims. ${ }^{16}$ Meanwhile, France practiced a different pattern but with the same blunder. When the British tried to unite several ethno-religious communities under a feudal puppet government, the French separated ethno-religious territories with a pseudo-democratic form of republic government but at the same time arranged acculturation in the border region. Such acculturation, initially intended as a buffer zone for the sustainability of control, turned out to spark chronic and terrible sectarian

${ }^{12}$ Impression of "recklessness" for example could be seen in a statement by Winston S. Churchill in the formation of the Israeli-Palestinian borders that became the conflict center until today. "I created Transjordan with the stroke of a pen on a Sunday afternoon in Cairo." Cited from L. Collins, \& D. Lapierre, O Jerusalem!, (New York: Simon \& Schuster, 1972), p. 83

${ }^{13}$ D. Fromkin, A Peace to End All Peace..p. 17

${ }^{14}$ J. Keegan, The Iraq War, (New York: Knopf, 2004), p. 14-15

${ }^{15}$ D. Fromkin, A Peace to End All Peace..p. 17, see juga p. 528

${ }^{16}$ Ahmed Rashid, Taliban: Militant Islam, Oil and Fundamentalism in Central Asia, p. 
conflict as witnessed between Syria and Lebanon. ${ }^{17}$

The series of the acts of violence in the region triggered by territorialization factor served as the background for the League of Nations convention which discussed specific agenda on terrorism as described above. Moreover, some illustration of the consequences of the above territorialization has left a lot of problems and served as a source of conflict. In fact, the conflicts that are full of violent acts of terror had trans-national impact and inspired separatist movements in various parts of the world in the coming decades.

Although the later acts of terror continued to grow, triggering World War II, and continued to bloom in the period of the cold war, an effort to articulate a consensus defining the concept of terrorism as a common enemy wss still struggling at the level of discourse and only emerged in academic circles. Walter Lacquer warned that the phenomenon was closely related to the intensity of competition of geopolitical domination among great powers involved in the Cold War that it would be impossible to bring the concept of terrorism into the legal sphere especially toward an international consensus. ${ }^{18}$ Such complicated definition also appeared from international efforts to re-address the concept of terrorism after the terror incident at the Munich Olympic Games 1972. The United Nations initiated an ad hoc Committee on Terror. However, after more than seven years of convening, this committee never came to an agreement and ended without producing significant decisions. ${ }^{19}$

The concept of terrorism began to tread the world of legal discourse in the 1970s when the FBI director, William Webster started categorizing some federal criminal cases that might threaten the stability of the domestic security as terrorism. However, it was in 1994 that the FBI began to apply terrorism as one of the federal criminal charges. ${ }^{20}$

The Stone Age was the prosecution against the bombing suspect of the FBI building in Oklahoma in 1994, Timothy Mc Veigh who was charged with terrorism. The reasoning of such legal suit lied in the damaging effects of the action of the defendant and the escalating public concerns in the wake of Mc Veigh case, the FBI officially defined terrorism as: 1).unlawful use of force or violence, 2). Non-combatant people and property as potential targets, 3).Having political, social, religious, ideological goals, 4).objectives which are

${ }^{17}$ D. Fromkin, A Peace to End All Peace..p. 17

${ }^{18}$ W. Lacquer, The New Terrorism: Fanaticism and the Arms of Mass Destruction, (Oxford and New York:

Oxford University Press, 1999), p. 1-2

${ }^{19}$ Muhammad Mustofa, "Memahami Terrorisme: Suatu Perspektif Kriminologis", Jurnal Kriminologi Indonesia, FSISIP UI, Vol. 2, No. 111, Desember 2002, p. 35

${ }^{20}$ B.L. Smith, Terrorism in America, (New York: New York University Press, 1994), p. 8 
pursued through coercion or intimidation. ${ }^{21}$

The FBI definition was almost similar to the version released by the US State Department a few months earlier. The US Department of State defined terrorism as "premeditated, politically motivated violence perpetrated against noncombatant targets by sub-national groups or clandestine agents, usually intended to influence an audience."22 Although so identical, the two definitions issued formally by the two formal institutions in the US were apparently creating some substantial debate in practice. First, the step FBI took to use terrorism clauses in the case of Timothy Mc Veigh ultimately proved to act individually in contrast to the perception of US Department of State underlining factor of actors acting collectively. Second, because the FBI scope of work, the focus was more on the context of domestic terrorism, while the US Department of State defined it as acts of violence that threaten global stability. Polemics on the definitions in internal state agencies of the US were certainly influential in determining a consensus on the certainty of the legal form that should be adopted by the country, although later the body of legislation, House of Bills, sought to take the initiative by removing the definition of terrorism as "the use of force or violent in violationof the criminal laws of the US or any state... that appears to be intended to achieve political or social ends." However, these efforts still did not provide solution for the definition to serve as a definite common reference. ${ }^{23}$

Polemics and controversies that still continue to shade the discussions among US public regarding the discourse on terrorism did not restrict other countries to participate in articulating the same definition. The limits set by the institutions in the US later served as the inspiration for other countries to ratify the rules on terrorisme. The definitions even are still in the stage of the controversy that became a global discourse and was adopted as the preliminary draft of the agenda for a common agreement on international terrorism convention in the forum of the United Nations in the early 21 st century.

Agenda of discussion on the definition of terrorism has been on the negotiating table of the UN General Assembly since 2000. In 2002, the session taking the theme Comprehensive Convention on International Terrorism has arrived at the draft that defines terrorism as planned criminal acts that cause death or severe bodily harm and serious damage to property or vital public facilities,

${ }^{21}$ B.L. Smith, Terrorism in America, p. 8. See Juga Bruce Hoffman, Inside Terrorism, (New York: Columbia University Press, 1998), p. 38

${ }^{22}$ US Department of State, Patterns of Global Terrorism 1994, April 1995, p. vi

${ }^{23}$ Mary H. Cooper, "Definitions of Terrorism often Vary", the CQ Research, vol. 5, No. 27, July 1995, p. 646 
and impede the effectiveness of legitimate state government, causing huge economic/financial, and are intended to intimidate the public or to overthrow a legitimate government, or to force the legitimate international institution to make or abandon a policy. ${ }^{24}$

The definition is actually not so controversial. Debate arose precisely on the implications of opinion among the delegates. Deadlock occurred at point whether such definition also applies to acts of violent 'crime' committed by an official of the Armed Forces of a country or a group of freedom fighters. In the midst of this discussion, a concept of "State Terrorism" which is the possibility of a terror act committed by a state against its people or against other sovereign state appeared. Thalif Deen described that the heat of the debate at the negotiating table rested on a few crucial basic issues such as: what are the differences between a terrorist and a freedom fighter organization? Are there exceptions to the armed forces of an official government if they take actions that fall into the category of terrorism? If there are no exceptions, to which extent do such actions fit into State Terrorism? ${ }^{25}$ Coordinators of the negotiation backed by a majority of delegates from Western countries and then asked for some exceptions to the definition of terrorism such as: acts carried out based on international laws and rules of the United Nations Charter, acitivies carried out by the Armed Forces during armed conflicts, and acts of the Armed Forces should be regulated also by international legal agreements. ${ }^{26}$ Objections arose from the delegates that are members of the Organization of Islamic Conference (OIC). They also asked for the exception to acts undertaken by those who fight for independence from foreign occupation force, and it also does not need to be regulated in a separate international legal agreement as long as it conforms with international rules that already exist. ${ }^{27}$

Endless dilemma of the quest for a definitive concept of terrorism lies on two poles of opposite legal interests. On the one hand, the international community needs a comprehensive definition which allows the formulation of legal penalty against terrorist acts in order to protect human rights, maintain the stability of a country in carrying out legitimate political policies, and ensure

${ }^{24}$ UN General Assembly, "Report of the Ad Hoc Committee", $6{ }^{\text {th }}$ Session, 28 January -1 February 2002, as cited from Thalif Deen, "POLITICS: U.N. Member States Struggle to Define Terrorism”, IPS, 25 July 2005

${ }^{25}$ Thalif Deen, "POLITICS: U.N. Member States Struggle to Define Terrorism”, IPS, 25 July 2005

${ }^{26}$ UN General Assembly, "Report of the Ad Hoc Committee", $6{ }^{\text {th }}$ Session, 28 January -1 February 2002, seperti dikutip dari Thalif Deen, "POLITICS: U.N. Member States Struggle to Define Terrorism”, IPS, 25 July 2005

${ }^{27}$ UN General Assembly, "Report of the Ad Hoc Committee", $6^{\text {th }}$ Session, 28 January -1 February 2002, seperti dikutip dari Thalif Deen, "POLITICS: U.N. Member States Struggle to Define Terrorism", IPS, 25 July 2005 
the security and peace of the world. On the other hand, however, the legal concept must be precise, not ambiguous, convicting an infringement with the exclusion of the legitimate action. ${ }^{28}$ Here lies all the problems. Divergent views on an international level concerning examples of acts that can be categorized as terrorism are so broad because the fundamental values of each group of interests are at stake.

\section{TERRORISM: A SHORT CUT CONCLUSION}

"One man's terrorist is another man's freedom fighter". The byword is so famous in each study of terrorism. Bruce Hoffman, for example, stated that 'terrorism' is a pejorative word that has negative and highly subjective connotation. The word will certainly be associated by one party toward another, regardless of the objectives of the action. ${ }^{29}$ In the same vein, Sami Zeidan argued that to label terrorism will depend on the position on which you stand. The political interests are far beyond the levels of legal objectivity. Its definition can vary according to what the political objectives to achieve. During the Soviet occupation, Osama bin Laden and the Taliban in the eyes of the West were the Mujahidin who fought for freedom and therefore were supported by the CIA. Now they occupy the top position in the list of most wanted terrorists in the world. ${ }^{30}$

All the ambiguous concepts of terrorism are also reflected in survey reports of several studies. Alex P. Scmid and Albert J. Jongman (et.al.) recorded more than 109 definitions of terrorism with 22 detailed different elements. ${ }^{31}$ Walter Lacqueur also counted more than 100 definitions on terrorism. In his view, the conical conclusion of the overall definition lies only in the formula that terrorism is the action involving violence and / or threats of violence that are not much different from war, oppressive policies, or a bar fight. ${ }^{32}$ Contemporary literature marks at least four characteristics of terrorist acts; first, acts or threats of violence with the aim of political impact. Second, neatly

${ }^{28}$ This opinion was quoted by the expressions given by Carlos F. Diaz-Paniagua, one of the coordinators of the UN General Assembly agenda of Comprehensive Convention on International Terrorism, see C.F. Diaz-Paniagua, Negotiating Terrorism: The Negotiation Dynamics of Four UN Counter-Terrorism Treatises 1997-2005, (New York: City University of New York, 2008), p. 47

${ }^{29}$ Bruce Hoffman, Inside Terrorism, p. 32

${ }^{30}$ Sami Zeidan, "Desperately Seeking Definition: The International Community's Quest for Identifying the Specter of Terrorism”, Cornell International Law Journal, vol. 36, 2004, p. 491-492

${ }^{31}$ Alex P. Scmid, Albert J. Jongman (et.al.), Political Terrorism: A New Guide to Actors, Authors, Concepts, Data Bases, Theories, and Literature, (New Brunswick, New Jersey: Transaction Books, 1988), p. 5-6.

${ }^{32}$ Walter Laqueur, The New Terrorism..., p. 6 
arranged and planned, measurable and sistematic actions. Third, terrorist acts disregard the prevailing laws of war. Keempat, terrorist acts are intended to produce psychological effects that are devastating and reach a wide target outside the actual target or victims of the action. ${ }^{33}$

However, the above characteristics still cannot dilute the core dilemmatic issues. The definition points that distinguish between violence committed by terrorists and that by revolutionary fighters. 'Terrorism', as the impact of the actual action, is a 'weird' and devastating term. A word that has the capacity to stigmatize, deligitimize, dehumanize and debasing anyone it labels. Ben Saul called it as follows "ideologically and politically loaded... implies moral, social and value judgement and is slippery and much-abused..." ${ }^{\prime 3}$ Terrorism is a 'slippery' term and often abused. Jason Burke added that there are many ways to define it, and it is filled with the user's tactics subjectively. ${ }^{35}$

In short, the prevailing definition of terrorism will be determined by who the mainstream parties who use it and how it is implementated. Support from the media voicing the concept to the public also determines the format of the definition. In the wake of devastating terror attacks in the US in 2001 and the subsequent actions of counter-terror has no doubt put the US and its coalitions in the war on terror as the main actors in determining the definition of terrorism. Needless to say, the parties targeted as the prey in this war campaign bear the title of 'terrorists'.

\section{THE SO-CALLED ISLAMIC TERRORISM}

Regardless of the ambiguity of the definition of terrorism, in fact, the top list of major terrorist preys are Muslim groups or organizations that often commit violent acts in the name of Islam. International media also aggressively preach the violent acts that occurred in other parts of the world by putting the involvement of Muslim militants as headlines. A series of such phenomena then that raises a more absurd discourse with the headline "Islamic terrorism".

The discourse of Islamic terrorism is similar to elusive fog if not mirage. It looks as if it were real but it has no tangible form. Pairing a word that connotes evil with a religious place as sources of kindness is problematic. In fact, pair of the two words is a hot conversation on a global stage. Islamic terrorism, in some of the literature reffered to as Islamist terrorism, has become a trending

${ }^{33}$ William F. Shugart II, “An Analytical History of Terrorism: 1945-2000”, Public Choice, vol. 128,2006 , p. 10

${ }^{34}$ Ben Saul, "Defining 'Terrorism' to Protect Human Rights", Sydney Law School Legal Studies Research Paper, No. 08-125, 2008, p. 11.

${ }^{35}$ Jason Burke, Al Qaeda, ch.2, p.22 
topic in political and academic discourse in the early decade of this century.

The majority of the discussion about current issues of terrorism almost certainly cite the discussion on Islam and Muslims. This is very ironic. Terrorism which is significant political acts of violence aimed at creating a tense situation is labeled on Islam, the religion which literally means gentleness, submission, and promotion of good here and in the hereafter. This irony also continues when the word 'Islamic terrorism' is repeatedly called but only refers to a common sense where there is no specific definition that describes its specification. Assumptions that arise and become a picture when the term Islamic terrorism is used which generally refers to the notion as defined by Wikipedia as follows: "a form of religious terrorism committed by extremists of Islam mostly for the religious beliefs and sometimes on achieving varying political ends again in the name of religion".

Violence with religious motives is neither new nor exclusively carried out by adherents of a particular religion. Historically, there have been a lot of occurrences in the documentation of violence one group against another in the name of belief. However, classifying which actions are terrorism and which are not is a big problem because it is highly filled with political and rhetorical implications. The Irish Republican Army (IRA) saw their group as pursuing religious holy struggle against the domination of England in the region. Timothy Mc Veigh did not show the slightest remorse destroying the FBI building with hundreds of people being killed in it because he viewed his action as a way to stop 'repression' of formal government against the religious group in which he was affiliated. Aum Shinrikyo also thought that he has done 'holy war' against the 'apostasy' the Japanese government when releasing the nerve gas killer "Nerin" in a subway station in Tokyo. No matter how sacred the purpose behind their actions, the label of 'terrorists' springs to people's minds when their names are mentioned.

Mainstream great powers that influence the policy direction of the world and the intense media campaign have a dominant role in determining to which group the terrorism label is pinned. The discourse situation of geo-politics and international policy has also proved to be the same. William F. Shugart II noted that since the end of the second world war there have been three categories of large waves of evolution of violence that were labeled terrorism by types of background and goals. First, shortly after the end of World War II, acts of violence that had implications were generally based on the separatist terror and the purpose of the establishment of a new sovereign state. This sort of movement was limited and its scope domestic. Second, originated around the 1960s until the fall of the Berlin Wall in 1989, terrorism began to take 
shape as a cross-country movement of left wing inspired by the view of antiliberalism and anti-Americanism to be more specific. The context of the Cold War between the US-led Western bloc with the Soviet-led Eastern bloc also was colored by violent acts of terror in this period, in which terrorism was seen as the Eastern Bloc sporadic attacks by using extreme factions to attack the interests of the West Bloc in various parts of the world. This phase was often regarded as the starting point of 'globalization' of terrorism. Third, the last evolution of the wave of terrorism incarnated in the form of religiously motivated violence, in this case especially Islam. This form of terrorism is the culmination of the latest evolution of the previous circuits and has been transformed in a way that is more brutal and horrific. ${ }^{36}$. Why is the form of the third wave of terrorism often associated with Islam and described as "very scary"?

Further description of the Shugart II's classification shows that: first, terrorism is often defined simply as the violence that creates a tense atmosphere and gets a lot of public attention. Second, terrorism is almost always embedded to movement of anti-status quo that resists the government power. Third, the trend of world's political discourse plays a role in determining where the issue of terrorism is centered. The end of the cold war was characterized by the Soviet Union's collapse which also marked the end of main focus of discourse on global politics surrounding the conflict between the West and the East which had lasted for nearly three decades. In the midst of the vacuum, news about violence involving Muslims dominated the international media publications. Insurgencies carried out by groups of Muslims to the oppression of the ruling government gained sympathy moral support, fund, even soldiers and weapons from other Muslim groups regarded as a phenomenon of the new trans-national violent conflict. Victims of violence involving Muslim groups throughout the 1990s, had reached three times the total number of victims of terrorism in the four previous decades'Analysts further alleged that the roots of this new political phenomenon of violence is inspired by the resurgence of two Muslim groups throughout history that have always opposed each other; The Iranian Revolution was initiated by Shia and the success of the Mujahidin who were Sunni majority in ousting the Soviets from Afghanistan. The motive to fight in the name of Islam with the sacred aim by the Islamic groups is seen as a more effective way in the resistance revolution than political purposes. The conclusion can illustrate the growth of terrorism discourse of political violence that suddenly became religiously motivated violence and subsequently placing Islam as the main actor in the focus of the discourse of terror and terrorism.

${ }^{36}$ William F. Shugart II, “An Analytycal History of Terrorism”,..p. 27-32 


\section{CLOSING: GENEALOGY OF ISLAMIC TERRORISM DISCOURSE}

The discourse genealogical approach is derived from the fact that a text always refers to other texts that also rely on other texts that have been there before. ${ }^{37}$ Therefore, the discourse of forming a worldview through a mechanism involves the use of resources of linguistic and cultural order system that exist in the interpretation of a particular social phenomenon. The use of this genealogical approach is expected to help in understanding how "knowledge" formed at this time is formulated through a naturalization process that occurs in a span of time, space and discursive practices. There are so many aspects of the details that might explain the origins of Islamic terrorism discourse construction in detail. However, there are at least three general explanations that could describe how the concept of Islamic terrorism was understood and used in its present form.

First and foremost is that the narrative discourse of 'Islamic terrorism' is now rooted in assumptions, theories and concepts of knowledge that has previously been established in the scope of the field of study of terrorism narrative discourse. Despite growing so rapidly and becoming the focus of recognized independent academic study in the post period of the terrorist attacks of September 11, the concept of 'Islamic terrorism' seems to have emerged from two previous decades. Its embryo is derived from the concept of' religious terrorism which is most widely used and widely cited by influential literature which was developed by David Rapoport in his paper entitled "Fear and Trembling: Terrorism in Three Religious Tradition" which was published in the journal American Political Science Review in 1984. ${ }^{38}$ The Rapoport's work was followed by a number of core texts written by other influential academics and established a reputation as a primary source of reference in the study of 'Islamic terrorism. ${ }^{39}$ Concepts, narrative construction and the labels that

${ }^{37}$ Roxanne Doty, "Foreign Policy as Social Construction: A Post-Positivist Analysis of U.S. Counterinsurgency Policy in the Philippines", International Studies Quarterly, 37 (1993), p. 297-320. See Juga Jennifer Milliken, “The Study of Discourse in International Relations: A Critique of Research and Methods", European Journal of International Relations, 5:2, (1999), P. 225-54.

${ }^{38}$ David Rapoport, 'Fear and Trembling: Terrorism in Three Religious Traditions', American Political Science Review, 78 : 3 (1984), pp. 658-677

${ }^{39}$ Among some of the literature that is widely cited by other works in the field of the study of terrorism and Islam are Bruce Hoffman, Inside Terrorism, (NewYork: Columbia University Press, 1998), and Walter Laqueur, The New Terrorism: Fanaticism and the Arms of Mass Destruction, (New York: Oxford University Press, 1999), Mark Juergensmeyer, Terror in the Mind of God: The Global Rise of Religious Violence, (Berkeley, CA: University of California Press, 2000), Jessica Stern, Terror in the Name of God: Why Religious Militants Kill, (New York: Harper Collins, 2003), dan Magnus Ranstorp, 'Terrorism in the Name of Religion', Journal of International Affairs, 50: 1 (1996), pp. 41-62. 
became the core of discourse of studies developed by the references then received a very strong authority and political influence. The forming factors are a close tripartite network connection between this terrorism experts and the circles of power policy holders who are also supported by senior journalists in the international media influence. ${ }^{40}$

Second, the core focus of the study which is central in the discourse of Islamic terrorism and the narrative patterns and the label that are used have been derived from a long tradition of Orientalist studies in the study of the Middle East region and the study of religion in the Arab culture. The orientalist literature study has been growing rapidly following the elevation of events of turmoil in the Middle East in the 1970s and 1980s such as the massacre at the Olympics in 1972 in Munich, world oil turbulence in 1973, hostage crisis at US embassy in Iran that accompanied the Revolution in 1979, Salman Rushdie case as well as cases of terrorism involving kidnapping and piracy throughout the 1980s. The orientalist types of study became more intense and more prominent with the terrorist attacks of 9/11 and the war on terror. One of literature's most dominant influence on international relations studies with orientalist perspective is the work of Samuel Huntington entitled The Clash of Civilization? The Essay was written in 1993 and its title is quoted from the writings of Bernard Lewis has become an important antecedent and widely reproduced in the discourse of Islamic terrorism which is in circulation today. ${ }^{41}$ In addition, figures such as Bernard Lewis, Noah Feldman, Raphael Patai and other Middle East experts often sit with other experts in the field of terrorism and become main advisors and expert staff for the US government in the formulation of action to counter terror. It was the catalyst for the transmission of viewpoint which then decorated orientalist discourse of Islamic terrorism in the process of political policies. ${ }^{42}$

Third, a lot of Islamic terrorism discourse refers to the long tradition of cultural stereotypes and biased representations of the media that often portray

${ }^{40}$ An indication of the fact of bureaucrat-academia-journalists connections is that writers like Bernard Lewis, Bruce Hoffman, Steven Simon, Jessica Stern, Daniel Benjamin, dan Richard Perle worked in agencies such as the government's strategic national Security Council and the Ministry of Defense. They also exchanged information with senior journalists at CNN, VoA, The New York Times, LA Times, Washington Post, Newsweek and USA Today such as Thomas Friedman, Charles Krauthammer, David Brooks, William Kristol, Martin Peretz, Norman Podhoretz, and Judith Miller. See L. Ali Khan, Phenomenology of International Terrorism: Understanding Islamic Militancy, (Leiden: Martinus Nijhoff Publisher, 2006), p. 206209.

${ }^{41}$ Samuel Huntington, 'The Clash of Civilizations?', Foreign Affairs, 72: 3 (1993), p. 22-49. While the works of Bernard Lewis in question is Bernard Lewis, 'The Roots of Muslim Rage', Atlantic Monthly, 266: 3 (1990), p. 47-60

${ }^{42}$ As'ad AbuKhali, 'Book Review: "The Islam Industry” and Scholarship', Middle East Journal, 58: 1 (2004), p. 130-8.See also, Edward Said, Covering Islam, p. 150 
Islam and Muslims as 'the enemy'. In describing the Muslims, the mainstream media usually tend to use reporting framework with a focus on violence, threats, extremism, fanaticism and terrorism, although there are also some orientalist visual tradition in which Muslims are portrayed as exotic and mysterious. ${ }^{43}$ The forms of cultural representation have survived for so long and are embedded so strongly. The reason is that it reflects the perspective of socio-Western culture that fear and worry that other oriental parties are stereotyped which has been ongoing since the imperial era. Many also argue that the dichotomy of the orientalist views are deliberately preserved as a form of new style imperialism.

In addition to the three primary discursive traditions above, especially after 9/11, the expression 'Islamic terrorism' also inherited the concepts and terms that have been used in the narratives of previous global political culture discourse. Phrases such as 'good war' for example is discourse that is often used by the Western allies during the war against fascism in World war II and the Cold war. Likewise with other terms such as 'civilized vs. barbaric war', 'rogue states', 'enemy within', weapons of mass destruction, the eternal war between good and evil are a long series of cultural narrative which has nowbecome the central display of discourse of the so-called Islamic terrorism.

\section{REFERENCES}

AbuKhali, A. (2004). "The Islam Industry and Scholarship." in Middle East Journal, 58: 1-7.

Burgess, M. (2013). “A Brief History of Terrorism." Washington DC: Center for Defense Information. Retrieved from https://www.ciaonet.org/wps/ bum09/ on 23 Juli 2013.

Conte, A. (2010). Human Rights in the Prevention and Punishment of Terrorism. Heidelberg: Springer.

Cooper, M. H. (1995). "Definitions of Terrorism often Vary." in the CQ Research. vol. 5, No. 27. P: 646.

Crenshaw, M. (1995). Terrorism in Context. Penn: Penn State University Press.

Croft, S. (2006). Culture, Crisis and America's War onTerror. Cambridge: Cambridge University Press.

Deen, T. (2005). "POLITICS: U.N. Member States Struggle to Define Terrorism.” in IPS. 25 July 2005.

Diaz-Paniagua, C.F. (2008). Negotiating Terrorism: The Negotiation Dynam-

${ }^{43}$ Elizabeth Hurd, 'Appropriating Islam: The Islamic Other in the Consolidation of Western Modernity’, Critique: Critical Middle Eastern Studies, 12: 1 (2003), P. 25-41. 
ics of Four UN Counter-Terrorism Treatises 1997-2005. New York: City University of New York.

Doty, R. (1993). "Foreign Policy as Social Construction: A Post-Positivist Analysis of U.S. Counterinsurgency Policy in the Philippines." in International Studies Quarterly. 37.

El-Fadl, K. (ed.). (2002). Shattered Illusions: Analyzing the War on Terrorism. Bristol: Amal Press.

Fromkin, D. (2004). "A Peace to End All Peace" in L. Collins, \& D. Lapierre. O Jerusalem! New York: Simon \& Schuster and J. Keegan. The Iraq War. New York: Knopf.

Halliday, F. (2002). Two Hours that Shook the World - September 11, 2001: Causes \& Consequences. London: Saqi Books.

Harper, D. (2013). “Terrorism.” in Dictionary.com: Online Etymology Dictionary, at http://dictionary.reference.com/browse/terrorism, retrieved on 23 Juli 2013.

Hilton, I. (2001). “The Pashtun code.” in New Yorker, 77(38), (2001), p: 58-71. Hoffman, B. (1998). Inside Terrorism. New York: Columbia University Press.

Huntington, S. (1993). “The Clash of Civilizations?” in Foreign Affairs. 72: 3 p: $22-49$.

Hurd, E. (2003). "Appropriating Islam: The Islamic Other in the Consolidation of Western Modernity." in Critique: Critical Middle Eastern Studies. 12: $1 \mathrm{p}: 25-41$.

Jackson, J. (2005). Writing the War on Terrorism: Language, Politics and Counterterrorism. Manchester: Manchester University Press.

Juergensmeyer, M. (2000). Terror in the Mind of God: The Global Rise of Religious Violence. Berkeley, CA: University of California Press.

Khan, A. (2006). Phenomenology of International Terrorism: Understanding Islamic Militancy. Leiden: Martinus Nijhoff Publisher.

Laqueur, W. (1999). The New Terrorism: Fanaticism and the Arms of Mass Destruction. New York: Oxford University Press.

Lewis, B. (1990). “The Roots of Muslim Rage." in Atlantic Monthly. 266: 3.

Milliken, J. (1999). "The Study of Discourse in International Relations: A Critique of Research and Methods." in European Journal of International Relations. 5:2. P: 225-254.

Mustofa, M. (2002). "Memahami Terrorisme: Suatu Perspektif Kriminologis.” in Jurnal Kriminologi Indonesia. FSISIP UI, Vol. 2, No. 111. p: 35.

Pati, R. (2009). Due Process and International Terrorism. Leiden: Martinus Nijhoff Publisher.

Poole, E. \&John Richardson. (2006). Muslims and the News Media. London: I.B. Tauris. 
Pustogarov, V. (1996). "Fyodor Fyodorovich Martens (1845-1909) - a Humanist of Modern Times." in International Review of the Red Cross (IRRC). No. 312, May-June 1996. P: 300-314.

Rapoport, D. (1984). "Fear and Trembling: Terrorism in Three Religious Traditions." in American Political Science Review. 78: 3.

Rashid, A. (2001). Taliban: Militant Islam, Oil and Fundamentalism in Central Asia. New Haven and London: Yale Nota Bene.

Sadowsky, Y. (1996). "The New Orientalism and the Democracy Debate." in Joel Beinin \& Joe Stork (eds.). Political Islam. Berkeley, CA: University of California Press.

Said, E. (1997). Covering Islam: How the Media and the Experts Determine How We See the Rest of the World. London: Vintage.

Saul, B. (2008). "Defining 'Terrorism' to Protect Human Rights." in Sydney Law School Legal Studies Research Paper. No. 08-125.

Scmid, A.P., Albert J. Jongman (et.al.). (1998). Political Terrorism: A New Guide to Actors, Authors, Concepts, Data Bases, Theories, and Literature. New Brunswick, New Jersey: Transaction Books.

Sheehan, J. (2004). Reel Bad Arabs: How Hollywood Vilifies a People. Northampton, MA: Interlink Publishing Group.

Shugart II, W.F. (2006). "An Analytical History of Terrorism: 1945-2000." in Public Choice, vol. 128, p: 10.

Smith, B.L. (1994). Terrorism in America. New York: New York University Press

Stern, J. (2003). Terror in the Name of God: Why Religious Militants Kill. New York: HarperCollins.

Ranstorp, M. (1996) “Terrorism in the Name of Religion.” in Journal of International Affairs. 50: 1.

Richardson, J. (2004). (Mis)Representing Islam: The Racism and Rhetoric of British Broadsheet Newspapers. Amsterdam: John Benjamins.

Takeyh, R. \& Nikolas Gvosdev. (2004). "Radical Islam: The Death of an Ideology?" in Middle East Policy, 11: 4.

The 9/11 Commission. (2004). Final Report of the National Commission on Terrorist Attacks Upon the United States. New York: W. W. Norton \& Co.

UN General Assembly. (2002). Report of the Ad Hoc Committee. $6^{\text {th }}$ Session, 28 January - 1 February 2002.

US Department of State. (2015). “Significant Terrorist Incidents, 1961-2003: A Brief Chronology." In a report by US Dept of State retrieved from: http://www.state.gov/r/pa/ho/pubs/fs/5902pf.htm.

US Department of State. (1995). Patterns of Global Terrorism 1994. 
Williamson, M. (2009). Terrorism, War and International Law: The Legality of the Use of Force against Afghanistan in 2001. London: Ashgate Publishing.

Zeidan, S. (2004). "Desperately Seeking Definition: The International Community's Quest for Identifying the Specter of Terrorism." in Cornell International Law Journal. vol. 36, p: 491-492. 